\title{
TECHNOLOGICAL PEDAGOGICAL CONTENT KNOWLEDGE (TPACK) IN PRE-SERVICE AND IN-SERVICE CHEMISTRY TEACHER TRAINING: A SYSTEMATIC LITERATURE REVIEW
}

\author{
Thaygra Severo Bernardes ${ }^{\mathrm{a}, *}$ \\ Agostinho Serrano de Andrade Neto ${ }^{\mathrm{a}}$ \\ ${ }^{a}$ Mathematics and Science Teaching Graduate Program, Lutheran University of Brazil, Brazil \\ *Corresponding author. E-mail address: thaygra@rede.ulbra.br
}

\begin{abstract}
To guide the integration of Information and Communication Technologies (ICT) in the classroom, the theoretical model Technological Pedagogical Content Knowledge (TPACK), proposed by Mishra and Koehler in 2006, reinforces the importance of connecting pedagogical, technological, and content knowledge of teachers. This research sought to investigate the literature on how the theoretical model TPACK is being used for the integration of technology in Chemistry teaching. This investigation was based on a Systematic Literature Review (SLR), reaching a sample of 23 articles published in scientific journals from 2006 to 2019. In general, the researches that composed this SLR uses the theoretical model TPACK in a more theoretical way and mostly in in-service teacher training. The lack of research in the Brazilian context signals the need for more work supported by this framework, which can lead to practices that are more aligned with the contemporary needs of Chemistry teacher training.
\end{abstract}

Keywords: TPACK, chemistry teachers, educational technologies, 21 st-century abilities.

\section{CONHECIMENTO TECNOLÓGICO PEDAGÓGICO DO CONTEÚDO (TPACK) NA FORMAÇÃO INICIAL E CONTINUADA DE PROFESSORES DE QUÍMICA: UMA REVISÃO SISTEMÁTICA DE LITERATURA}

Resumo. Para orientar a integração das Tecnologias da Informação e Comunicação (TIC) em sala de aula, o modelo teórico Conhecimento Tecnológico Pedagógico do Conteúdo (TPACK), proposto por Mishra e Koehler em 2006, reforça a importância de conectar o conhecimento pedagógico, tecnológico e do conteúdo dos professores. Esse trabalho buscou investigar na literatura como o modelo teórico TPACK está sendo empregado para a integração da tecnologia no ensino de Química. Essa investigação baseou-se em uma Revisão Sistemática de Literatura (RSL), alcançando uma amostra de 23 artigos publicados em periódicos científicos no período de 2006 a 2019. Em geral, as pesquisas que compuseram a essa RSL utilizam o modelo teórico TPACK de forma mais teórica e em sua maioria na formação continuada de professores. A escassez de pesquisas no contexto brasileiro sinaliza a necessidade de mais trabalhos amparados por esse referencial, o que pode levar a práticas mais alinhadas às necessidades contemporâneas da formação de professores de Química.

Palavras-chave: TPACK, professores de quimica, tecnologias educacionais, habilidades do século 21.

\section{Introduction}

The integration of Information and Communication Technologies (ICT) in teacher training enables constant digital updating of teachers, which is almost mandatory for contemporary education. This is especially important for teachers working in higher 
education courses, as they can stimulate changes in other levels of education (Kenski, 2015). Accordingly, opportunities that promote the professional development of these teachers in a way that updates their knowledge bases can facilitate the appropriation of the use of technologies in teaching (Bransford et al., 2007; Darling-Hammond; Bransford, 2005). As well as the establishment of public policies that guide permanent training processes in the area of digital technologies are fundamental (Machado; Vasconcelos; Oliveira, 2017).

The Chemistry teaching has been often made with activities that lead to the memorization of information, formulas, and knowledge that restrict students' learning and contribute to demotivation in learning and studying Chemistry. In general, the obstacles faced by students when learning the contents of this curricular component are not considered, such as the difficulties of abstraction of concepts, elaboration, and understanding of scientific models and the emergence of alternative concepts (Melo; Santos, 2012).

Flores (2014) emphasizes that the teacher must use technology not only as a tool but integrate it into his pedagogical practice and in the development of the school curriculum. Hence, the teacher needs to know what technological resources are available in their work environment and their potential.

To guide the integration of technologies in the field of teaching, Mishra and Koehler proposed in 2006 a theoretical model designated Technological Pedagogical Content Knowledge (TPACK). This was elaborated based on Shulman's model: PCK Pedagogical Content Knowledge (1986; 1987), integrating the Technological Knowledge component. According to Mishra and Koehler (2006), Shulman did not contemplate technology and its relationship with pedagogy and content, because at the time of his studies the use of technologies in teaching was not considered.

In the TPACK framework, represented by a Venn diagram with three overlapping circles (Figure 1), technological knowledge is a knowledge base as important as pedagogical skills and content knowledge (Mishra; Koehler, 2006). The model proposes the intertwining of three knowledge bases: content $(\mathrm{CK})$, pedagogy $(\mathrm{PK})$, and technology (TK), obtaining from the intersections other four knowledge bases. These seven knowledge bases that constitute the TPACK propose a set of knowledge necessary for teachers for a productive integration of technologies in teaching (Mishra; Koehler, 2006; Koh; Chai; Tsai, 2012):

- TK - Technological Knowledge: knowledge about technological tools;

- PK - Pedagogical Knowledge: knowledge of teaching methodologies;

- CK - Content Knowledge: knowledge of the content to be taught;

- TCK - Technological Content Knowledge: knowledge of how to represent content using technology;

- TPK - Technological Pedagogical Knowledge: knowledge of the use of technology to implement different teaching methodologies;

- PCK - Pedagogical Content Knowledge: knowledge of which teaching methodologies can be used to teach a specific content;

- TPACK - Technological Pedagogical Content Knowledge: knowledge of the use of technology to implement teaching methodologies for different content to be taught. 


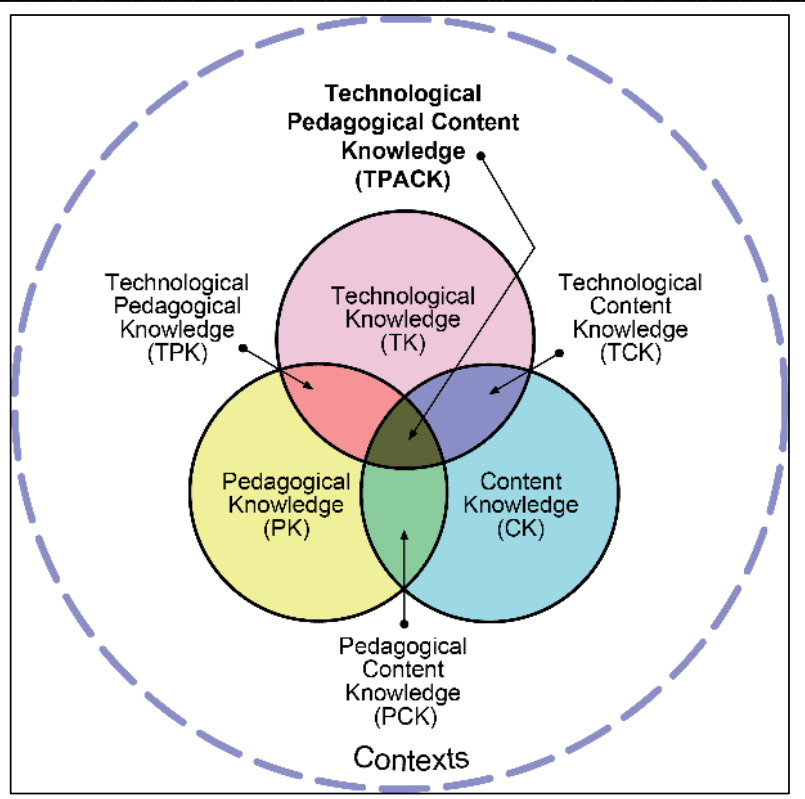

Figure 1 - TPACK framework

Source: Mishra e Koehler (2006)

The theoretical TPACK model connects technology to the curriculum and makes it possible to understand how teachers perceive the three basic forms of knowledge and their intersections. According to Koehler et al. (2014), there are several approaches to assess the TPACK of teachers in pre-service or in-service training, being the most used instruments in research: the interview, observation, self-report surveys, open surveys, and performance evaluations. Consequently, the TPACK reference when used in practice provides a complex and situated educational construction (Harris; Hofer, 2011).

Assuming the relevance of this theoretical framework for teacher training, this research aimed to investigate the literature on how the theoretical model TPACK is being used for the integration of technologies in Chemistry teaching.

\section{Method}

A Systematic Literature Review (SLR), as guided by Sampaio and Mancini (2007), comprises the procedures for (1) elaborating the research question, (2) defining the search method, (3) determining the inclusion and exclusion Criteria of articles, and (4) analysis of the relevance of the literature found for the work. This kind of investigation provides a better orientation for the following researches and identifies the methodological trends of the area under study.

To investigate the use of the TPACK framework in the context of the Chemistry teacher training, the research question that guided the research was: How is the TPACK framework being used to integrate technologies in Chemistry teaching?

The search period was limited between the years 2006 (the year that the authors Mishra and Koehler presented the TPACK to the scientific community) and 2019. The Education Resources Information Center (ERIC), Scopus, SciELO, Science Direct, and Web of Science databases were consulted. Free access to the bases was granted by the university where the research was conducted, carried out through the Periódicos CAPES website. To also contemplate the Brazilian academic production, a search was made directly in the Brazilian scientific journals: Educação Temática Digital, Ciência \& Educação, Ensaio: Pesquisa em Educação em Ciências, Revista Brasileira de Educação, Educação e Pesquisa e Acta Scientiae. Before-mentioned journals were chosen because they were evaluated as Qualis A1/A2 (Teaching Area - Quadrennium 2013-2016) by the 
Coordenação de Aperfeiçoamento de Pessoal de Nível Superior (CAPES - a Foundation within the Ministry of Education in Brazil).

The descriptor used in the search was "TPACK and Chemistry", aiming to search for articles that used the TPACK model in Chemistry teaching. As criteria for inclusion of articles, they were defined as (I) article published in a scientific journal; (II) peerreviewed articles; and (III) be written in Portuguese, English, or Spanish. As for the exclusion criterion for articles, it was defined as: (I) research carried out specifically with Chemistry teachers. Table 1 presents the research steps:

Table 1 - Synthesis of the research method

\begin{tabular}{|c|c|c|}
\hline Research Question & Search Method & Inclusion and Exclusion Criteria \\
\hline \multirow{4}{*}{$\begin{array}{l}\text { How is the TPACK } \\
\text { framework being used } \\
\text { to integrate } \\
\text { technologies in } \\
\text { Chemistry teaching? }\end{array}$} & $\begin{array}{l}\text { Search period: } \\
2006 \text { to } 2019\end{array}$ & \multirow{2}{*}{$\begin{array}{l}\text { Inclusion criteria: } \\
\text { (I) Article published in a scientific } \\
\text { journal; } \\
\text { (II) Articles peer-reviewed; } \\
\text { (III) Be written in Portuguese, } \\
\text { English, or Spanish. }\end{array}$} \\
\hline & $\begin{array}{c}\text { Database: } \\
\text { Education Resources Information Center (ERIC) } \\
\text { Scopus } \\
\text { SciELO } \\
\text { Science Direct } \\
\text { Web of Science }\end{array}$ & \\
\hline & $\begin{array}{c}\text { Brazilian scientific publications: } \\
\text { Educação Temática Digital } \\
\text { Ciência \& Educação } \\
\text { Ensaio: Pesquisa em Educação em Ciências } \\
\text { Revista Brasileira de Educação } \\
\text { Educação e Pesquisa } \\
\text { Acta Scientiae }\end{array}$ & \multirow[t]{2}{*}{$\begin{array}{l}\text { Exclusion criterion: } \\
\text { (I) Research carried out specifically } \\
\text { with Chemistry teachers. }\end{array}$} \\
\hline & $\begin{array}{c}\text { Descriptors: } \\
\text { "TPACK and Chemistry" }\end{array}$ & \\
\hline
\end{tabular}

Source: research data

After searching the databases and journal websites, the collected particles were organized according to the country, scientific journal, publication year, type of teacher training (pre-service or in-service), and application of the TPACK framework (theoretical or experimental). In the latter, articles that cite the TPACK framework as a theoretical reference for the integration of technologies in Chemistry teaching were considered as theoretical applications. The experimental application, on the other hand, was attributed to articles that make use of the TPACK model, such as the application of TPACK assessment instruments on teachers.

Subsequently, based on the set of articles, the current perspectives of the study of the TPACK framework in the Chemistry teaching were discussed, verifying the possibilities of expanding this kind of investigation, mainly in the Brazilian context.

\section{Results and Discussion}

The search for scientific articles of interest in the Education Resources Information Center (ERIC), Scopus, SciELO, Science Direct, and Web of Science databases resulted in 54 documents. In the Brazilian scientific journals Educação Temática Digital, Ciência \& Educação, Ensaio: Pesquisa em Educação em Ciências, Revista Brasileira de Educação, Educação e Pesquisa e Acta Scientiae, no articles were found.

Following the systematic literature review procedures proposed here, the sample of articles published in scientific journals that matched the research objective was reduced 
to 23 articles. This reduction was because 31 articles did not match one of the inclusion/exclusion criteria: research conducted specifically with Chemistry teachers. The articles excluded from the final sample demonstrate investigations with teachers who teaching Science in early childhood or elementary education.

The 23 articles, which present the content of interest to the investigation in the period from 2006 to 2019, were organized in Table 2:

Table 2 - The final sample of articles from the systematic literature review

\begin{tabular}{|c|c|c|c|c|c|}
\hline Article & Country & Scientific Journal & $\begin{array}{l}\text { Publication } \\
\text { Year }\end{array}$ & $\begin{array}{l}\text { Teacher } \\
\text { Training }\end{array}$ & $\begin{array}{l}\text { Framework } \\
\text { TPACK Use }\end{array}$ \\
\hline $\begin{array}{l}\text { Can YouTube it? Providing chemistry teachers } \\
\text { with technological tools and enhancing their } \\
\text { self-efficacy beliefs }\end{array}$ & Israel & $\begin{array}{l}\text { Chemistry Education } \\
\text { Research and Practice }\end{array}$ & 2013 & In-service & Experimental \\
\hline $\begin{array}{l}\text { I like Facebook: Exploring Israeli high school } \\
\text { chemistry teachers' TPACK and self-efficacy } \\
\text { beliefs }\end{array}$ & Israel & $\begin{array}{l}\text { Education and } \\
\text { Information } \\
\text { Technologies }\end{array}$ & 2017 & In-service & Experimental \\
\hline $\begin{array}{l}\text { Assessing the Effectiveness of using YouTube } \\
\text { Videos in Teaching the Chemistry of Group I } \\
\text { and VII Elements in a High School in Lesotho }\end{array}$ & Lesotho & $\begin{array}{l}\text { African Journal of } \\
\text { Research in } \\
\text { Mathematics, Science } \\
\text { and Technology } \\
\text { Education }\end{array}$ & 2019 & In-service & Theoretical \\
\hline $\begin{array}{l}\text { Effects of "Environmental Chemistry" Elective } \\
\text { Course Via Technology-Embedded Scientific } \\
\text { Inquiry Model on Some Variables }\end{array}$ & Turkey & $\begin{array}{l}\text { Journal of Science } \\
\text { Education and } \\
\text { Technology }\end{array}$ & 2014 & In-service & Experimental \\
\hline $\begin{array}{l}\text { Improving Science Student Teachers' Self- } \\
\text { perceptions of Fluency with Innovative } \\
\text { Technologies and Scientific Inquiry Abilities }\end{array}$ & Turkey & $\begin{array}{l}\text { Journal of Science } \\
\text { Education and } \\
\text { Technology }\end{array}$ & 2015 & In-service & Theoretical \\
\hline $\begin{array}{l}\text { Development of pre-service chemistry } \\
\text { teachers' technological pedagogical content } \\
\text { knowledge }\end{array}$ & Turkey & $\begin{array}{l}\text { Chemistry Education } \\
\text { Research and Practice }\end{array}$ & 2018 & Pre-service & Experimental \\
\hline $\begin{array}{l}\text { Learning How to Teach Chemistry with } \\
\text { Technology: Pre-Service Teachers' } \\
\text { Experiences with Integrating Technology into } \\
\text { Their Learning and Teaching }\end{array}$ & Australia & $\begin{array}{l}\text { Journal of Science } \\
\text { Teacher Education }\end{array}$ & 2014 & In-service & Theoretical \\
\hline $\begin{array}{l}\text { Examining the Validity of the technological } \\
\text { pedagogical and content knowledge (TPACK) } \\
\text { framework for preservice chemistry teachers }\end{array}$ & China & $\begin{array}{l}\text { Australasian Journal of } \\
\text { Educational } \\
\text { Technology }\end{array}$ & 2017 & Pre-service & Experimental \\
\hline $\begin{array}{l}\text { A framework for teachers' integration of ICT } \\
\text { into their classroom practice }\end{array}$ & Ireland & $\begin{array}{l}\text { Computers and } \\
\text { Education }\end{array}$ & 2011 & In-service & Experimental \\
\hline $\begin{array}{l}\text { Teachers personalize videos and animations of } \\
\text { biochemical processes: results from a } \\
\text { professional development workshop }\end{array}$ & Israel & $\begin{array}{l}\text { Chemistry Education } \\
\text { Research and Practice }\end{array}$ & 2019 & In-service & Theoretical \\
\hline $\begin{array}{l}\text { Chemistry teacher professional development } \\
\text { using the technological pedagogical content } \\
\text { knowledge (TPACK) framework }\end{array}$ & Ethiopia & $\begin{array}{l}\text { African Journal of } \\
\text { Chemical Education }\end{array}$ & 2014 & Pre-service & Theoretical \\
\hline $\begin{array}{l}\text { Embedding Probeware Technology in the } \\
\text { Context of Ocean Acidification in Elementary } \\
\text { Science Methods Courses }\end{array}$ & $\begin{array}{l}\text { United } \\
\text { States of } \\
\text { America }\end{array}$ & $\begin{array}{l}\text { Journal of Science } \\
\text { Education and } \\
\text { Technology }\end{array}$ & 2017 & Pre-service & Theoretical \\
\hline $\begin{array}{l}\text { Integration of open educational resources in } \\
\text { undergraduate chemistry teaching-a mapping } \\
\text { tool and lecturers' considerations }\end{array}$ & Israel & $\begin{array}{l}\text { Chemistry Education } \\
\text { Research and Practice }\end{array}$ & 2016 & In-service & Theoretical \\
\hline $\begin{array}{l}\text { Integrating the interactive whiteboard and peer } \\
\text { coaching to develop the TPACK of secondary } \\
\text { science teachers }\end{array}$ & Taiwan & $\begin{array}{l}\text { Computers and } \\
\text { Education }\end{array}$ & 2010 & In-service & Experimental \\
\hline
\end{tabular}




\begin{tabular}{|c|c|c|c|c|c|}
\hline $\begin{array}{l}\text { Designing and implementing an integrated } \\
\text { technological pedagogical science knowledge } \\
\text { framework for science teachers professional } \\
\text { development }\end{array}$ & Greece & $\begin{array}{l}\text { Computers and } \\
\text { Education }\end{array}$ & 2010 & In-service & Experimental \\
\hline $\begin{array}{l}\text { Teacher design in teams as a professional } \\
\text { development arrangement for developing } \\
\text { technology integration knowledge and skills of } \\
\text { science teachers in Tanzania }\end{array}$ & Tanzania & $\begin{array}{l}\text { Education and } \\
\text { Information } \\
\text { Technologies }\end{array}$ & 2016 & In-service & Theoretical \\
\hline $\begin{array}{l}\text { Attitudes among chemistry teachers towards } \\
\text { increasing personal competencies in applying } \\
\text { ICT }\end{array}$ & Slovakia & $\begin{array}{l}\text { Chemistry-Didactics- } \\
\text { Ecology-Metrology }\end{array}$ & 2017 & In-service & Theoretical \\
\hline $\begin{array}{l}\text { New Pedagogies on Teaching Science with } \\
\text { Computer Simulations }\end{array}$ & Canada & $\begin{array}{l}\text { Journal of Science } \\
\text { Education and } \\
\text { Technology }\end{array}$ & 2011 & In-service & Theoretical \\
\hline $\begin{array}{l}\text { Enabling Pre-service Chemistry Teachers' } \\
\text { Development of Technological, Pedagogical, } \\
\text { and Content Knowledge (TPACK) through } \\
\text { Case-Based Lesson Planning }\end{array}$ & Turkey & $\begin{array}{l}\text { Eğitim Fakültesi } \\
\text { Dergisi }\end{array}$ & 2019 & Pre-service & Experimental \\
\hline $\begin{array}{l}\text { South African university students' attitudes } \\
\text { towards chemistry learning in a virtually } \\
\text { simulated learning environment }\end{array}$ & $\begin{array}{l}\text { South } \\
\text { Africa }\end{array}$ & $\begin{array}{l}\text { Chemistry Education } \\
\text { Research and Practice }\end{array}$ & 2019 & Pre-service & Theoretical \\
\hline $\begin{array}{l}\text { Using wiki to create a learning community for } \\
\text { chemistry teacher leaders }\end{array}$ & Israel & $\begin{array}{l}\text { Chemistry Education } \\
\text { Research and Practice }\end{array}$ & 2013 & In-service & Theoretical \\
\hline $\begin{array}{l}\text { Technological Pedagogical Knowledge of } \\
\text { Content: building of concepts and teaching } \\
\text { skills }\end{array}$ & Brazil & Perspectiva & 2017 & Pre-service & Theoretical \\
\hline $\begin{array}{l}\text { Exploring the structure of TPACK with video- } \\
\text { embedded and discipline-focused assessments }\end{array}$ & Taiwan & $\begin{array}{l}\text { Computers and } \\
\text { Education }\end{array}$ & 2017 & In-service & Experimental \\
\hline
\end{tabular}

Source: research data

When analyzing the number of articles published by country (Figure 2), Israel, Turkey, and Taiwan stand out, with $21.7 \%, 17.4 \%$, and $8.7 \%$ of the total articles, respectively, together they are responsible for nearly $50 \%$ of the scientific publication on TPACK in the context of Chemistry education.

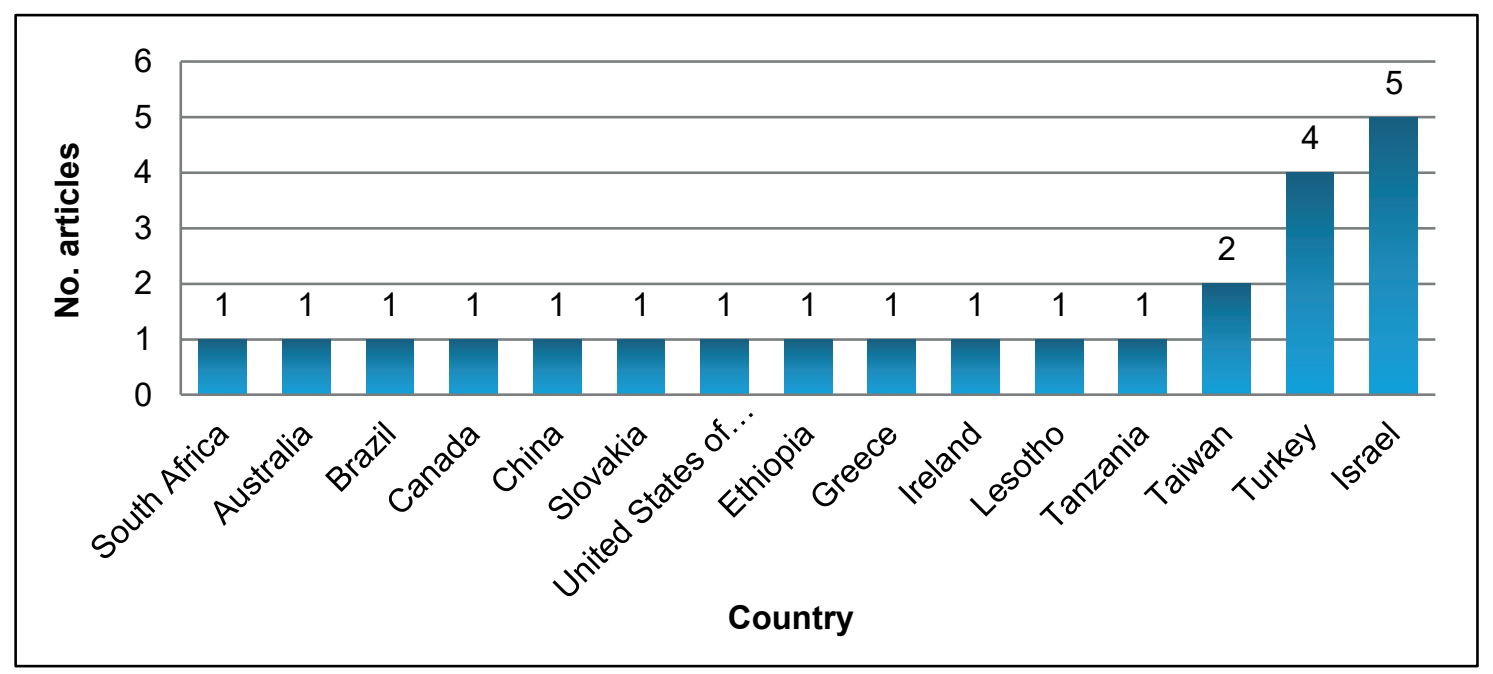

Figure 2 - Distribution of articles by country

Source: research data

This result is lined up with that obtained in the literature review by Chai, Koh, and Tsai (2013), where these countries also stood out in the number of articles involving the 
TPACK framework. Concerning the Brazilian research, only one article was found (Sousa; Lima; Christino, 2017), indicating that in the context of the Chemistry teacher training, it is necessary to expand the studies that address the TPACK framework in Brazil.

In Figure 3, regarding the journals where the articles were published, it noticeable that the 11 related journals are about science education, chemistry education, technological education, or educational technologies. Chemistry Education Research and Practice stand out with $26.1 \%$ of articles, Computers and Education with $17.4 \%$, and Journal of Science Education and Technology with 17.4\%.

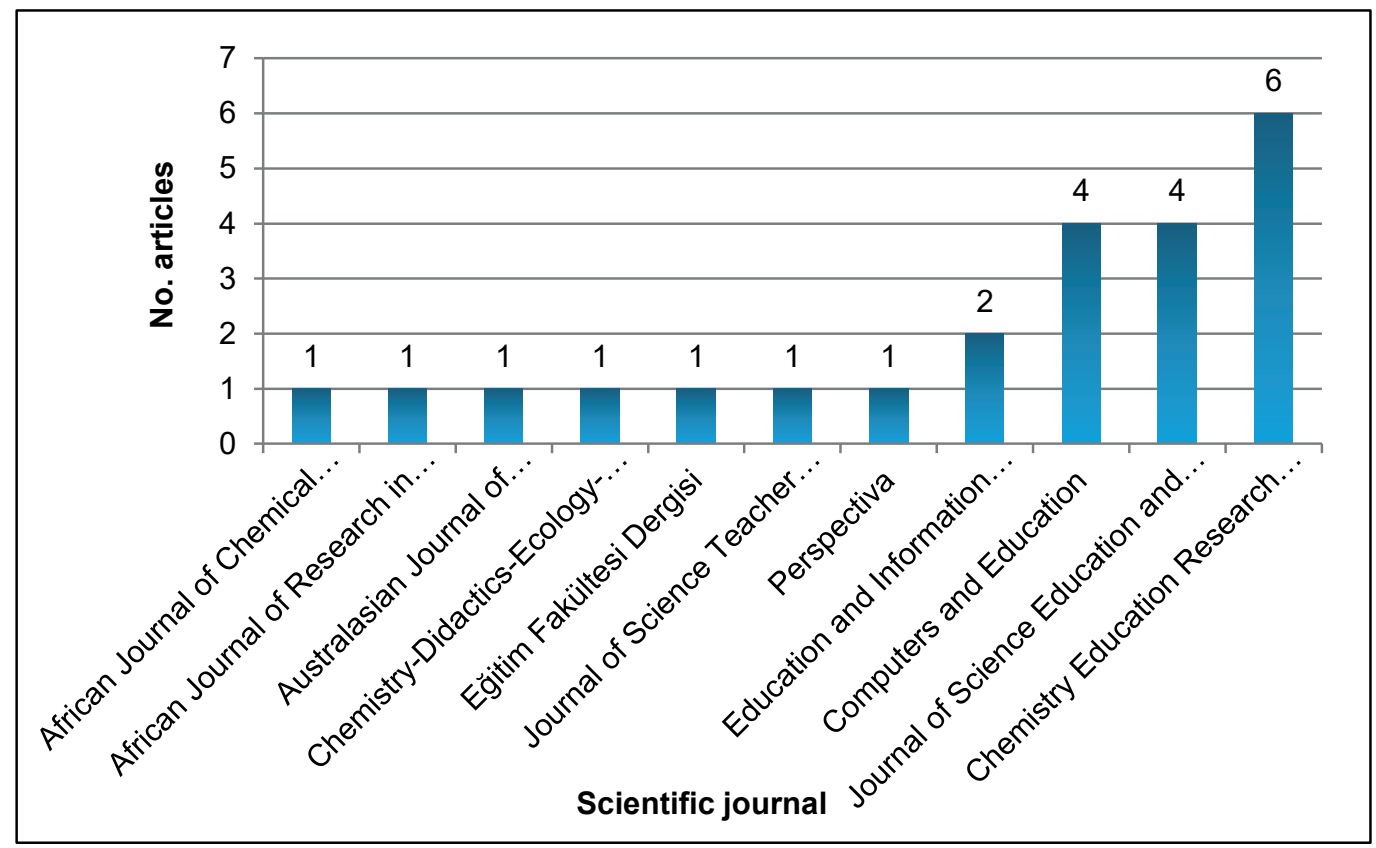

Figure 3 - Distribution of articles by the scientific journal Source: research data

In 2006 Mishra and Koehler published their TPACK framework and it took four more years for the publishing of the first publications in Chemistry education. As shown in Figure 4, between 2010 and 2016 there are 01 to 03 publications per year; and between 2017 and 2019 there are 01 to 06 publications per year. Regardless of the number of publications has increased over the years, investigations with Chemistry teachers can be further explored concerning the integration of technologies guided by the TPACK framework. 


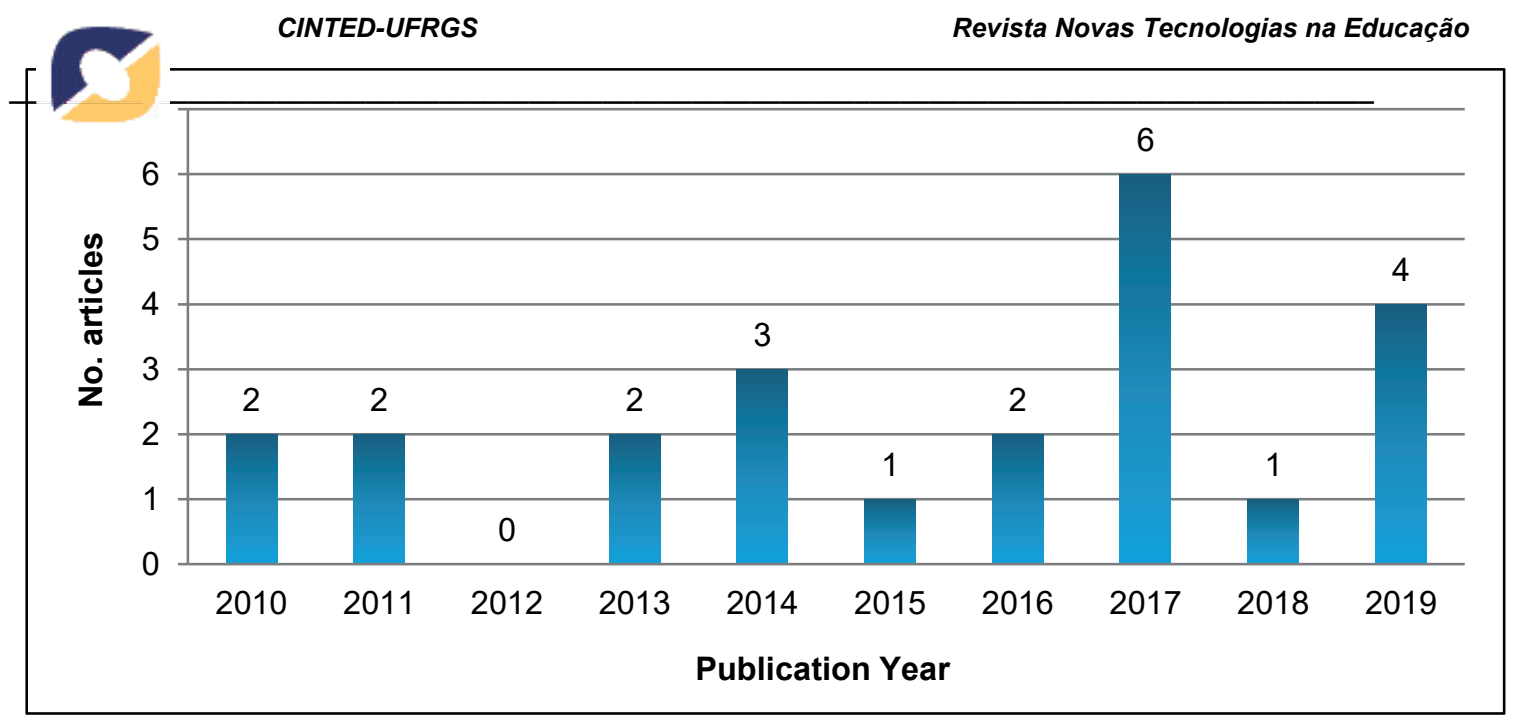

Figure 4 - Distribution of articles by year

Source: research data

To reach the research objective and answer the research question "How is the TPACK framework being used to integrate technologies in Chemistry teaching?", the articles found were analyzed regarding the kind of teacher training (pre-service or inservice) and application of the TPACK framework (theoretical or experimental), obtaining the following distribution:

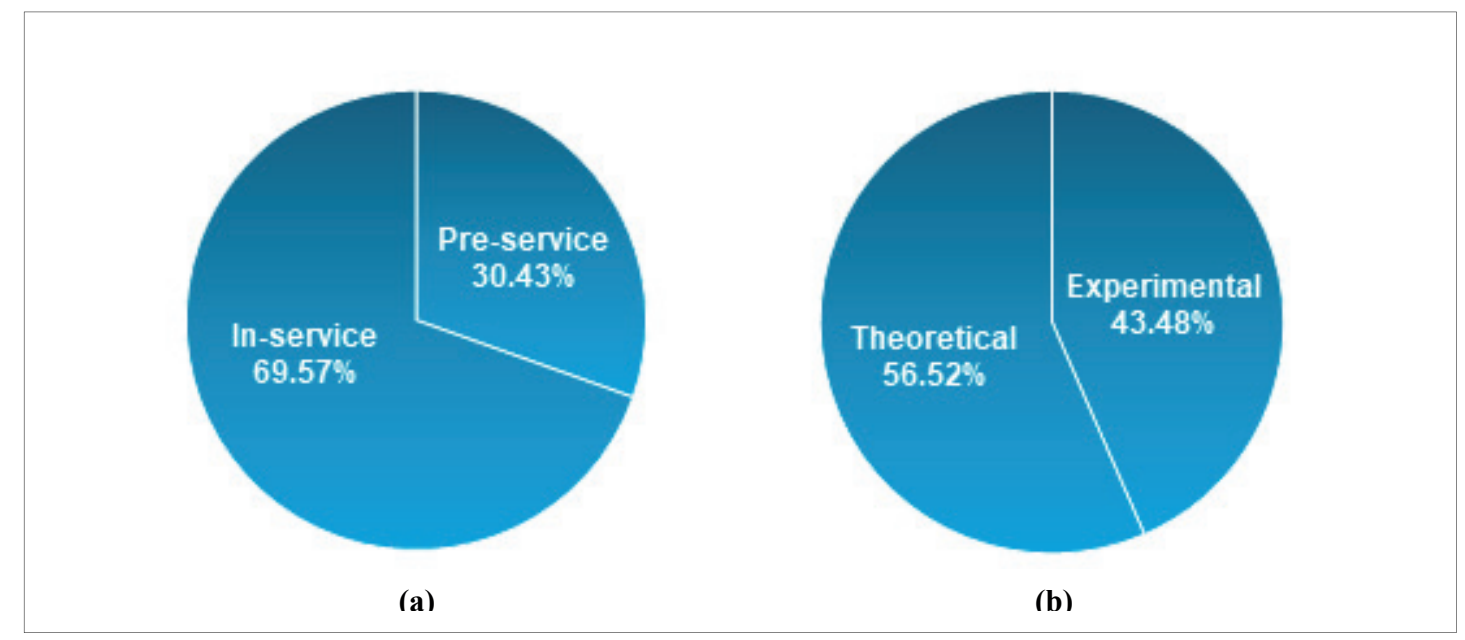

Figure 5 - Distribution of articles by (a) kind of teacher training and (b) application of the TPACK framework

Source: research data

As shown in Figure 5, 69.57\% of the articles were conducted with in-service teacher training and $30.43 \%$ with pre-service teacher training. This smaller number of research related to pre-service teacher training has previously been evidenced in a literature review presented by Wang, Schmidt-Crawford, and Jin (2018). The authors point out the use of the TPACK framework as an interesting resource for application since the pre-service teacher training, to provide training for future teachers on the integration of technologies in their pedagogical practices. Concerning the application of the TPACK framework, it is noticed that there is equity in the investigated articles, where $43.48 \%$ present the model only as a theoretical framework for the integration of technologies in the teaching of Chemistry and $56.52 \%$ use the model to its methodologies, such as the application of teachers' assessment surveys.

An example of a theoretical application is the research conducted by Kafyulilo, Fisser Voogt (2016), where 12 teachers of Chemistry, Physics, and Biology participated 
in a workshop on educational technologies at a high school in Tanzania. The teachers prepared classes together and, through observations and interviews, were evaluated concerning their perceptions about educational technologies and teamwork. Even though the authors supported their theoretical framework by citing the TPACK framework, the research did not aim to investigate the integration of pedagogical, technological, and content knowledge.

As an example of an experimental application, there is the research of Deng et al. (2017), who propose the evaluation of the TPACK of 280 undergraduate chemistry students at a Chinese university. The authors applied the self-report survey by Chai et al. (2011) and the rubric evaluation proposed by Harris et al. (2010) during an optional course that addressed the use of technologies in the Chemistry teaching. The study revealed that the discipline provided the undergraduate students with a greater ability to integrate technologies into the developed lesson plans, nevertheless, it was realized that undergraduate students could improve concerning their content and pedagogical knowledge bases.

Overall, the articles present research that proposed to provide theoretical and methodological subsidies about the integration of technologies in the pre-service and inservice Chemistry teacher training. There are articles that the TPACK framework only guides the use of educational technologies, being cited only as a theoretical framework. In others, the main objective of the article is to measure and evaluate the TPACK of teachers, having investigations conducted with their instruments and others applying instruments previously validated and commonly used by researchers in the field.

\section{Conclusions}

The TPACK framework used as a theoretical model can guide the teacher training by developing technological skills that are used in an integrated manner with specific content and educational objectives. The integration of educational technologies in the school context may depend on several factors, such as the elaboration of flexible pedagogical proposals, misconceptions about the contributions of technologies, school infrastructure, the teacher's level of technological knowledge, class learning, etc. (Mishra; Koehler, 2006).

This review explored research, which was supported by the TPACK framework for the integration of technologies in Chemistry teaching, and found the possibility of developing research precisely in the field of teacher training in Brazil. By expanding and deepening national research, it will be possible to compare the Brazilian context with the international context of teacher training, especially for the exchange of knowledge and experiences.

\section{Acknowledgments}

This study was financed in part by the Coordenação de Aperfeiçoamento de Pessoal de Nível Superior Brasil (CAPES) - Finance Code 001.

\section{References}

BRANSFORD, J. D.; BROWN, A. L.; COCKING, R. R. Como as pessoas aprendem.

Cérebro, mente, experiência e escola. São Paulo: Editora Senac, 2007.

CHAI, C. S.; KOH, J. H, L.; TSAI, C. C. A review of Technological Pedagogical Content

Knowledge. Education Technology and Society, v. 16, n. 2, p. 31-51, 2013. 
CHAI, C. S.; KOH, J. H. L.; TSAI, C. C. Exploring the factor structure of the constructs of technological, pedagogical, content knowledge (TPACK). The Asia-Pacific Education Researcher, v. 20, n. 3, p. 595-603, 2011.

DARLING-HAMMOND, L.; BRANSFORD, J. Preparing teachers for a changing world: What teachers should learn and be able to do. San Francisco, CA: John Wiley \& Sons, 2005.

DENG, F. et al. Examining the Validity of the technological pedagogical and content knowledge (TPACK) framework for preservice chemistry teachers. Australasian Journal of Educational Technology, v. 33, n. 3, p. 1-14, 24 Jul. 2007.

FLORES, E. Tecnologias na Educação: ensinando e aprendendo com as TIC - Uma proposta para Educação do Campo. Porto Alegre: Secretaria de Educação do Rio Grande do Sul, 2014.

HARRIS, J.; GRANDGENETT, N.; HOFER, M. Testing a TPACK-based technology integration assessment rubric. In: MADDUX, C. D.; GIBSON, D.; DODGE, B. (Eds.). Research highlights in technology and teacher education. Chesapeake, VA: Society for Information Technology \& Teacher Education, 2010, p. 323-331.

HARRIS, J.; HOFER, M. J. Technological Pedagogical Content Knowledge in Action: A Descriptive Study of Secondary Teachers' Curriculum-Based, Technology-Related Instructional Planning. Journal of Research on Technology in Education, v. 43, n. 3, p. 211-229, 2011.

KAFYULILO, A.; FISSER, P.; VOOGT, J. Teacher design in teams as a professional development arrangement for developing technology integration knowledge and skills of science teachers in Tanzania. Education and Information Technologies, v. 21, n. 2, p. 301318, 4 Mar. 2016.

KENSKI, V. M. A urgência de propostas inovadoras para a formação de professores para todos os níveis de ensino. Revista Diálogo Educacional, v. 15, n. 45, p. 423-441, 2015.

KOH, J. H. L.; CHAI, C. S.; TSAI, C. C. Examining practicing teachers' perceptions of technological pedagogical content knowledge (TPACK) pathways: a structural equation modeling approach. Instructional Science, v. 41, n. 4, pp. 793-809, Jul. 2013.

KOEHLER, M. J. The Technological Pedagogical Content Knowledge Framework. In: SPECTOR, J. M. et al. (Eds.). Handbook of Research on Educational Communications and Technology. New York: Springer, 2014, p. 101-111.

MACHADO, J. C.; VASCONCELOS, M. C. C.; DE OLIVEIRA, N. R. Formação Inicial e Continuada de Professores: entre o discurso e a prática. Cadernos de Educação, Tecnologia e Sociedade, v. 10, n. 1, p. 13-27, 2017.

MELO, M. R.; SANTOS, A. O. Dificuldades dos licenciandos em química da UFS em entender e estabelecer modelos científicos para equilíbrio químico. In: XVI Encontro Nacional de Ensino de Química. Salvador, UFBA, 2012.

MISHRA, P.; KOEHLER, M. J. Technological Pedagogical Content Knowledge a framework for teacher knowledge. Teachers College Record, v. 108, n. 6, p. 1017-1054, 2006.

SHULMAN, L. S. Those Who Understand: knowledge growth in teaching. Educational Research, v. 12, n. 2, p. 4-14, 1986

SHULMAN, L. S. Knowledge and Teaching: Foundations of the new reform. Harvard Educational Review, v. 57, n.1, p. 1-22, 1987.

SOUSA, S. O.; LIMA, A.; CHRISTINO, R. Technological Pedagogical Knowledge of Content: building of concepts and teaching skills. Perspectiva, v. 35, n. 4, p. 1215-1239, 2017.

WANG, W.; SCHMIDT-CRAWFORD, D.; JIN, Y. Preservice Teachers' TPACK Development: A Review of Literature. Journal of Digital Learning in Teacher Education, v. 34, n. 4, p. 234-258, 2018. 